\title{
MOTYW TRONU-RYDWANU BOŻEGO W PISMACH Z QUMRAN I POCZĄTKI MISTYKI MERKĀBĀH
}

Motyw tronu Bożego o kształcie rydwanu (merkābāh) z wizji Ezechiela (Ez 1,4-28; 10), który stał się głównym przedmiotem rozważań w mistyce żydowskiej, pojawia się w dwóch pismach odnalezionych na Pustyni Judzkiej nad Morzem Martwym, mianowicie w dokumencie noszącym tytuł Pseudo-Ezechiel (4Q385 frag. 6) oraz w Pieśniach ofiary szabatowej (4Q405 frag. 20, kol. $2+$ frag. 21-22)1.

\section{POCZĄTKI MISTYKI TRONU-RYDWANU BOŻEGO (ma 'ăśēh merkābāh)}

Świątynia niebiańska ze znajdującym się w jej wnętrzu tronem Bożym o kształcie rydwanu (מרכבה, merkābāh) jest centralnym motywem żydowskich tradycji mistycznych zachowanych w pismach na temat pałaców niebiańskich (היכלות, hêkālôt $)^{2}$, spośród których do najważniejszych należą Hekhalot rabbati (tj. Księga

1 W zwojach z Qumran termin מרכבה, ,rydwan”, pojawia się 16 razy; oprócz tych dwóch wymienionych przypadków, w których jest określeniem tronu Bożego w kształcie rydwanu (4Q385 frag. 6, linie 6; 4Q405 frag. 20, kol. 2 + frag. 21-22, linia 8), termin ten występuje w swoim podstawowym znaczeniu, a więc jako środek transportu (4Q223-224 frag. 2, kol. 5, linia 29) oraz jako wóz bojowy (1QM 11,10; 4Q169 frag. 3-4, kol. 2, linia 3), zaś kilkanaście razy staje się określeniem istot niebiańskich (4Q286 frag. 1, kol. 2, linia 2; 4Q403 frag. 1, kol. 2, linia 15; 4Q405 frag. 20, kol. 2 + frag. 21-22, linia 3; linia 4; linia 5; linia 11; frag. 37, linia 1; frag. 47, linia 1; 11Q kol. 6, linia 3; kol. 7, linia 5; kol. 10, linia 7), a jedynie w dwóch miejscach jest określeniem tronu Bożego w kształcie rydwanu (), zob. M.G. Abegg, i in. (red.), The Dead Sea Scrolls Concordance, The Non-Biblical Texts from Qumran [Part One], Brill, Leiden - Boston 2003, t. I, s. 488.

2 Zob. C. Rowland, C.R.A. Morray-Jones, The Mystery of God: Early Jewish Mysticism and the New Testament (CRINT 12), Brill, Leiden - Boston 2009, s. 303; szerzej na temat mistyki żydowskiej, zwłaszcza jej początków, zob. G. Scholem, Jewish Gnosticism, Merkabah Mysticism, and Talmudic Tradition, The Jewish Theological Seminary of America, New York 1965; tenże, Mistycyzm żydowski i jego główne kierunki, tł. I. Kania, Spółdzielnia Wydawnicza „Czytelnik”, 
większa pałaców niebiańskich), Hekhalot zutarti (tj. Księga mniejsza pałaców niebiańskich), Ma 'aseh merkabah (tj. Dzieto rydwanu), Merkabah rabba (tj. Ksiegga większa rydwanu), jak również Sepher hekhalot (tj. Księga pałaców), znana bardziej pod tytułem Ksiegga Henocha hebrajska (3 Hen).

Na podstawie świadectw pochodzących z literatury rabinicznej (m.Chagiga 2,1-6; j.Chagiga 77a; b.Chagiga 11b-16a; b.Sanhedrin 80b) można wnioskować, że nurt mistycznej interpretacji tronu Bożego był już w pełni rozwinięty w II wieku po Chr. Natomiast wcześniej mistyka merkābāh rozwijała się w ramach apokaliptyki, na co wskazują opisy tronu Bożego w niebiosach, otoczonego niezliczoną liczbą istot niebiańskich, między innymi w Księdze strażników (1 Hen 14,18-23), Księdze Daniela (Dn 7,9-10), czy też w Apokalipsie Abrahama (ApAbr 18). Treścią wielu pism apokaliptycznych, zwłaszcza należących do grupy tzw. apokalips z podróżą pozaziemską, jest opis podróży wizjonera do sfery niebiańskiej, gdzie wędruje on przez poszczególne dziedzińce Świątyni, zbliżając się do miejsca najświętszego, w którym przebywa Bóg zasiadający na tronie.

Głównym źródłem mistycznych rozważań dotyczących tronu Bożego była tradycja biblijna, przede wszystkim wizja Ezechiela (Ez 1 i 10), ale również inne teksty (np. $1 \mathrm{Krl}$ 22,19; Iz 6,1-4; Dn 7,9-10), przy czym w żadnym z tych tekstów nie pojawia się termin מרכבה, ,rydwan”.

Wydaje się, że początki mistyki merkābāh sięgają czasu powstania Ksiąg Kronik (przełom IV i III w. przed Chr.), ponieważ w 1 Krn 28,18 na określenie tronu Bożego pojawia się słowo המרכבה, ,rydwan”, które najprawdopodobniej

\footnotetext{
Warszawa 1997; D.J. Halperin, The Faces of the Chariot: Early Jewish Responses to Ezekiel's Vision (TSAJ 16), Mohr Siebeck, Tübingen 1988; M. Himmelfarb, Heavenly Ascent and the Relationship of the Apocalypses and the Hekhalot Literature, „Hebrew Union College Annual” 59 (1988), s. 73-100; I. Gruenwald, From Apocalypticism to Gnosticism: Studies in Apocalypticism, Merkavah Mysticism and Gnosticism, Peter Lang, Frankfurt 1988; tenże, Apocalyptic and Merkavah Mysticism (AJEC 90), Brill, Leiden - Boston 2014 ( $2^{\text {nd }}$ revised edition); J. Dan, The Ancient Jewish Mysticism, MOD Books, Tel Aviv 1993; R. Elior, The Merkavah Tradition and the Emergence of Jewish Mysticism, w: Sino-Judaica: Jews and Chinese in Historical Dialogue. An International Colloquium, Nanjing, 11-19 October, 1996, red. A. Oppenheimer, Tel Aviv University, Tel Aviv 1999, s. 101-158; C. Newsom, Mysticism, w: Encyclopedia of the Dead Sea Scrolls, red. L.H. Schiffman, J.C. VanderKam, i in., Oxford University Press, Oxford 2000, t. I, s. 591-594; J.R. Davila, The Ancient Jewish Apocalypses and the Hekhalot Literature, w: Paradise Now: Essays on Early Jewish and Christian Mysticism (SBL. Symposium Series 11), red. A.D. DeConick, Society of Biblical literature, Atlanta 2006, s. 105-125; P. Schäfer, The Origins of Jewish Mysticism (TSAJ 112), Mohr Siebeck, Tübingen 2009.

3 Teksty hebrajskie głównych pism na temat pałaców niebiańskich znajdują się w: P. Schäfer, Synopse zur Hekhalot Literatur (TSAJ 2), Mohr Siebeck, Tübingen 1981; tenże, Geniza Fragmente zur Hekhalot Literatur (TSAJ 6), Mohr Siebeck, Tübingen 1984; H. Odeberg, 3 Enoch or the Hebrew Book of Enoch, Cambridge University Press, London 1928 (reprint: Ktav, New York 1973); przekład na język angielski wraz z wprowadzeniem i bibliografią do każdego z pism na temat pałaców niebiańskich: J.R. Davila, Hekhalot Literature in Translation: Major Texts of Merkavah Mysticism (JJTPSup 20), Brill, Leiden - Boston 2013.
} 
zostało tu użyte w znaczeniu technicznym, stosowanym w późniejszej mistyce żydowskiej: „(Dawid dał Salomonowi złoto) ... i na konstrukcję rydwanu (ולתבנית הפרכבה) cherubów ze złota, na (skrzydła) rozpostarte i okrywające Arkę Przymierza JHWH'. Wzmianka o konstrukcji rydwanu ze złotymi cherubami, które przykrywają swoimi skrzydłami Arkę Przymierza znajdującą się w miejscu najświętszym sanktuarium, bez wątpienia nawiązuje do Księgi Ezechiela (zob. Ez 1,10; 43,3-4). Z całą pewnością w znaczeniu technicznym słowo פרכבה (gr. پپ „rydwan” zostało użyte w Księdze Syracha (początek II w. przed Chr.) na określenie tronu Bożego z wizji Ezechiela, gdy autor stwierdza, że „Ezechiel oglądał widzenie chwały, którą On (tj. Bóg) ukazał mu na rydwanie cherubinów (€ $\epsilon i$

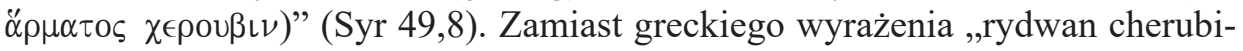

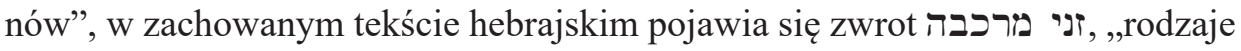
(stworzeń) rydwanu", który odnosi się do istot żyjących, jak również do innych elementów tronu-rydwanu, mianowicie kół, ognia, błyskawic ${ }^{4}$.

\section{MISTYKA TRONU-RYDWANU BOŻEGO W PISMACH Z QUMRAN}

Motyw tronu-rydwanu Bożego określonego jako merkābāh (מרכבה) pojawia się w tych tekstach qumrańskich, które nawiązując do wizji Ezechiela (zwłaszcza Ez 1) stanowią interpretację materiału biblijnego ${ }^{5}$. Należy przy tym stwierdzić, że Księga Ezechiela była inspiracją dla treści wielu pism z Qumran, wywierając znaczący wpływ na teologię wspólnoty ${ }^{6}$. O wielkiej popularności przesłania pro-

4 Zob. A. Tronina, Pierwsza Księga Kronik. Wstęp, przektad z oryginatu, komentarz (NKB.ST X/1), Edycja Świętego Pawła, Częstochowa 2015, s. 446; P.W. Skehan, A.A. Di Lella, The Wisdom of Ben Sira: A New Translation with Notes, Introduction and Commentary (AB 39), Doubleday, New York 1987, s. 544; tekst hebrajski Syr 49,8 za: P.C. Beentjes, The Book of Ben Sira in Hebrew: A Text Edition of All Extant Hebrew Manuscripts and a Synopsis of All Parallel Hebrew Ben Sira Texts (VTSup 68), Brill, Leiden 1997, s. 88.

5 Wśród pism odnalezionych w Qumran znajduje się również kilka dokumentów, w których chociaż nie pojawia się termin merkābāh , to jednak zawierają one elementy występujące w późniejszych pismach mistyki żydowskiej. W trzech dokumentach pojawia się motyw tronu Bożego w niebiosach, który jest różnie określany, mianowicie Błogosławieństwa i przekleństwa: ,siedziba honoru Twego” (4Q286 1, kol. 2, linia 1); Hymn samopochwalny: , ,tron mocy” (4Q491 frag. 11, kol. 1, linia 12) oraz aramejska Mesjańska apokalipsa: עסא מלכות ער , ,tron królestwa wiecznego” (4Q521, frag. 2+4, kol. 2, linia 7).

6 Zob. E. Gothenet, Influence d'Ezechiel sur la spiritualite de Qumran, „Revue de Qumran” 13 (1988), s. 431-439; B.Z. Wacholder, Ezekiel and Ezekielianism as Progenitors of Essenianism, w: The Dead Sea Scrolls. Forty Years of Research (STDJ 10), red. D. Dimant, U. Rappaport, Brill, Leiden - Magnes Press: Jerusalem 1992, s. 186-196; D. Dimant, The Apocalyptic Interpretation of Ezechiel at Qumran, w: Messiah and Christos. Studies in the Jewish Origins of Christianity (TSAJ 32), red. I. Gruenwald, i in., Mohr Siebeck, Tübingen 1992, s. 31-51; F. Garcia Martinez, L'interpretation de la Torah d'Ezechiel dans les ms. de Qumran, „Revue de Qumran” 
roka Ezechiela wśród członków społeczności qumrańskiej świadczy siedem rękopisów biblijnego tekstu Księgi Ezechiela (sześć znalezionych w Qumran i jeden na Masadzie), rękopisy Pseudo-Ezechiela, liczne cytaty, aluzje i reminiscencje znajdujące się w dokumentach niebiblijnych (np. CD, 1QH, 1QM, 4Q174, 4Q177, 4Q424). Księga Ezechiela cieszyła się dużym uznaniem wśród członków społeczności z Qumran z wielu powodów. Jednym z nich był „kapłański” charakter przepowiadania Ezechiela. Prorok Ezechiel koncentruje się na przekazywaniu swego orędzia z kapłańskiego punktu widzenia, między innymi, gdy chodzi o zbezczeszczenie Świątyni, smutek wynikający z faktu, że chwała Boża opuszcza Świątynię, akcentowanie lewickiego prawa, czy też nadzieja dotycząca ustanowienia nowej Świątyni oraz odnowionego kapłaństwa. Wszystkie te elementy pojawiają się również w pismach qumrańskich, stanowiąc świadectwo przekonań członków wspólnoty. Warto zwrócić uwagę, że niektóre elementy decydujące o tożsamości wspólnoty qumrańskiej oraz sposób jej samookreślania się, jak również określanie przeciwników wspólnoty, były zaczerpnięte z Księgi Ezechiela, między innymi nazywanie siebie „wygnańcami pustyni” (1QM 1,1-3; por. Ez 20,35), czy swoich wrogów „budowniczymi murów” (CD 4,19; 6,17; 19,30-35; 20,3-4; 4Q424 frag. 1, kol. 1, linie 3-5; por. Ez 13,9-16; 22,17-26). Jednakże najważniejszym elementem, który wpłynął na duże znaczenie Księgi Ezechiela w Qumran, jest niewątpliwie tematyka eschatologiczna, która zarówno u Ezechiela, jak i w pismach qumrańskich, opiera się na motywie ,powrotu z wygnania” i przyszłym odnowieniu. Prorok Ezechiel zapowiadał czas oczyszczenia na pustyni, który nastąpi przed odnowieniem (Ez 20,35). Ta zapowiedź jest interpretowana jako początek wojny eschatologicznej, która zakończy się ostatecznym zwycięstwem dobra (1QM 1,2-3). Ezechiel zapowiadał ukaranie kapłanów, którzy okazali się niewierni Bogu oraz odnowienie kapłaństwa, które zostanie oczyszczone. Wspólnota qumrańska była przekonana o zbezczeszczeniu kapłaństwa w Jerozolimie i widziała jego odnowienie i oczyszczenie, które będzie się wywodzić spośród jej członków. Wreszcie dla Ezechiela i wspólnoty qumrańskiej widocznym znakiem przyszłej odnowy stanie się powrót chwały Bożej do odnowionej Świątyni w nowej Jerozolimie. Ponieważ ziemska Świątynia została zbezczeszczona, członkowie społeczności z Qumran idealne sanktuarium upatrywali w Świątyni niebiańskiej. Stąd też w pismach qumrańskich kilkakrotnie pojawia się motyw chwały Boga zasiadającego na tronie-rydwanie w Świątyni niebiańskiej.

13 (1988), s. 441-452; tenże, The Apocalyptic Interpretation of Ezekiel in the Dead Sea Scrolls, w: Interpreting Translation: Studies on the LXX and Ezekiel. Fs. J. Lust (BETL 192), red. F. Garcia Martinez, M. Vervenne, Peeters Publishers, Leuven 2005, s. 163-176; M. Parchem, Księga Ezechiela w Qumran, „Collectanea Theologica” 77 (2007), nr 4, s. 103-138. 


\subsection{Pseudo-Ezechiel (4Q385 frag. 6, linie 5-15)}

Termin מרכבה, ,rydwan”, na określenie niebiańskiego tronu Bożego pojawia się w dokumencie zatytułowanym Pseudo-Ezechiel, który nawiązuje do wizji z Ez 1 i jest parafrazą materiału biblijnego. Wśród zwojów odnalezionych w Qumran znajduje się sześć rękopisów związanych z Księgą Ezechiela, które są określane jako Pseudo-Ezechiel (4Q385, 4Q386, 4Q385b, 4Q388, 4Q385c, fragmenty niezidentyfikowane, 4Q391). Tekst tych rękopisów zawiera opisy wizji objawionych prorokowi Ezechielowi oraz ich interpretacji. Niektóre z nich są znane z biblijnej Księgi Ezechiela, m.in. wizja ożywienia wyschniętych kości z Ez 37 (4Q385 frag. 2; 4Q386 frag. 1, kol. 1; 4Q388 frag. 7), wizja chwały Bożej z Ez 1 (4Q385 frag. 6), wizja przyszłej Świątyni z Ez 40-48 (4Q391 frag. 65 i 52), inne nie mają paraleli w tekście biblijnym, np. wizja dotycząca Egiptu i Babilonu (4Q386 frag. 1, kol. 2-3), chociaż niewątpliwie nawiązuje ona do Ez 29-32. Podobnie jak w materiale biblijnym Księgi Ezechiela, zachowane fragmenty qumrańskich opisów wizji oraz ich interpretacja są ujęte $w$ formę narracji autobiograficznej, jak również dialogu między Bogiem a prorokiem.

Opis wizji tronu-rydwanu Bożego znajduje się w 4Q385 frag. 6, linie 5-15 (dawniej: frag. 4). Dane paleograficzne wskazują, że rękopis pochodzi z drugiej połowy I wieku przed Chr. Tekst zachował się w stanie bardzo fragmentarycznym. Pierwsze cztery linie tego fragmentu należą najprawdopodobniej do poprzedzającej sekcji, poświęconej tematyce zmartwychwstania i odkupienia, o czym świadczy narracja w pierwszej osobie: ,i będzie mój lud” (linia 1), stanowiąca przemowę Boga skierowaną do proroka. Zmiana narracji na trzecią osobę następuje w linii 5, co wskazuje na początek nowej sekcji tekstu i podjęcie nowej tematyki dotyczącej wizji tronu-rydwanu Bożego (tj. merkābāh $)^{7}$. Nowa sekcja rozpoczyna się od formuły: „widzenie, które zobaczył Ezech[iel...]” (linia 5), która przybiera formę swoistego rodzaju tytułu dla następującego po nim tekstu (linie 6-15) ${ }^{8}$. Treścią kolejnych linii zachowanego tekstu jest opis rydwanu-tronu Bożego w nawiązaniu do wizji z Ez 1 (prawdopodobnie też Ez 10).

Zob. D. Dimant, J. Strugnell, The Merkabah Vision in Second Ezekiel (4Q384 4), „Revue de Qumran" 14 (1990), s. 337; D. Dimant, Resurrection, Restoration, and Time-Curtailing at Qumran, and in Early Judaism and Christianity, w: History, Ideology and Bible Interpretation in the Dead Sea Scrolls: Collected Studies (Forschungen zum Alten Testament, 90), red. D. Dimant, Mohr Siebeck, Tübingen 2014, s. 258.

8 Podobny tytuł pojawia się w 4Q385b: „i to są słowa Ezechiela”, zob. D. Dimant, 4QPseudo-Ezechiel a (DJD 30), s. 45. 
4Q385 frag. 6, linie 5-159:

5 Widzenie, które zobaczyl Ezech[iel...]

6 blask rydwanu i cztery istoty żyjace; istota żyjaca [...gdy szty nie odwracaly się]

7 do tyłu, na dwóch (nogach) szła każda istota żyjąca, a [jej] dwie no [gi...]

8 [n]ad [...] wjednej byto tchnienie, a ich twarze byty połaczone jedna $z$ dru[ga. I wyglad]

9 twa[rzy: jedna lwa, jed]na orła, i jedna wotu, i jedna czlowieka; i byt [a ręka]

10 czlowieka połaczona od pleców istot żyjących i przytwierdzona do [ich skrzydet] i kó[t,]

11 koło złaczone z kotem podczas poruszania się, i z dwóch stron k[ót byly plomienie ognia]

$12 \quad i$ w'rodku żarzacych się węgli byly istoty żywe, jak żarzace się węgle ognia [...]

13 i kola $i$ istoty żyjace $i$ kola; $i$ by [t ponad ich glowami firmament jak]

14 lód straszliw [y]. [I b]yt glos [sponad firmamentu...]

$15 \quad[\ldots]$

W tekście 4Q385 frag. 6, obok bezsprzecznych podobieństw w stosunku do biblijnego opisu wizji Ezechiela (Ez 1), pojawiają się również znaczące różnice. W opisie tronu-rydwanu Bożego autor dokumentu qumrańskiego używa tej samej terminologii i przedstawia w podobny sposób poszczególne elementy narracji, mianowicie wprowadzenie do wizji (linia 5; Ez 1,1.4), wzmianka o czterech istotach żyjących (linia 6; Ez 1,5), opis ich nóg, rąk i twarzy (linie 7-10; Ez 1,7-10), ich poruszanie się i wzmianka o kołach (linie 10-11; Ez 1,12), wygląd istot żyjących podobny do żaru ognia (linia 12; Ez 1,13), firmament ponad głowami istot żyjących (linie 13-14; Ez 1,22) oraz słyszalny głos (linia 14; Ez 1,25). Pojawiające się różnice dotyczą kolejności opisywanych elementów. Po pierwsze, w materiale biblijnym wzmianka o rękach istot żywych $($ Ez 1,8) następuje przed opisem ich czterech twarzy (Ez 1,10), podczas gdy w 4Q385 kolejność jest odwrotna. Po drugie, w Ez 1,13 żarzące się węgle ognia są wspomniane przed wzmianką o kołach (Ez 1,15), podczas gdy w tekście qumrańskim żarzące się węgle ognia są ukazane po opisie kół, co przypomina kolejność w Ez 10,2. Warto zauważyć, że w 4Q385 pojawiają się dodatki, których nie ma w wizji Ezechiela, które odnoszą się zwłaszcza do opisu poruszania się istot żyjących, co stanowi interpretację materiału biblijnego, mającą na celu wyjaśnienie trudności, jakie nasuwają się w związku z dość enigmatycznymi wypowiedziami (Ez 1,9.12.23; 10,11). W opisie poruszania się istot żyjących autor 4Q385 dodaje w linii 7 zwrot „do tyłu (אחור), oraz wyrażenie, że każda istota żyjąca szła „,na dwóch [nogach] (על שיםת)", co może nawiązywać do wizji z Iz 6,2, gdzie istoty otaczające tron Boży - określone jako

Tekst został opublikowany w: D. Dimant, 4QPseudo-Ezechiel a, w: Qumran Cave 4. XXI: Parabiblical Texts, Part 4: Pseudo-Prophetical Texts (DJD 30), red. D. Dimant, Clarendon Press, Oxford 2001, s. $42-51$ (+ pl. I); tłumaczenie własne, por. P. Muchowski, Rękopisy znad Morza Martwego, Qumran, Wadi Murabba'at, Masada, Nachal Chewer (BZ.TNT 5), Kraków 2000, s. 291-292. 
serafiny - mają sześć skrzydeł, z których dwa służą do przykrycia twarzy, dwa do przykrycia nóg i dwa do latania. Autor 4Q385 skraca w stosunku do materiału biblijnego opis twarzy istot żyjących, unikając w ten sposób powtórzeń pojawiających się w wizji Ez 1 (ww. 5-6 i w. 10). Ponadto na uwagę zasługuje opis sposobu połączenia rąk i pleców istot żyjących (linie 9-10), gdzie pojawia się termin דבקה, „przytwierdzona, połączona”, który nie występuje w wizji Ez 1, ale jest zaczerpnięty z 2 Krn 3,12, gdzie odnosi się do skrzydeł cherubinów znajdujących się w Świątyni. W linii 12, w odniesieniu do wyglądu istot żyjących stwierdza się, że są one ,jak żarzące się węgle ognia [...]”, co jest zaczerpnięte z Ez 1,13. W tekście qumrańskim te słowa są poprzedzone wyrażeniem: „w środku żarzących się węgli były istoty żywe", co stanowi interpretację tekstu biblijnego (Ez 1,13), który w kontekście opisu całej wizji jest dość zagadkowy (Ez 1,13). Warto zauważyć, że motyw ognia połączony z istotami niebiańskimi pojawia się w innych pismach z okresu Drugiej Świątyni. W opisie wizji niebiańskiego tronu Bożego, który znajduje się w Księdze strażników, pojawiają się „,ogniste cherubiny” (1 Hen 14,11). W Pieśniach ofiary szabatowej z Qumran również pojawiają się istoty „ogniste”, nazywane „duchami”, które otaczają tron Boży (4Q405 frag. 20 kol. 2, linie 9-10; 4Q403 frag. 1, kol. 2, linia 6) ${ }^{10}$. Wszystkie podobieństwa istniejące między 4Q385 frag. 6 i opisem wizji proroka Ezechiela wskazują, że tekst qumrański jest wzorowany na Ez 1 (i Ez 10), zaś różnice i dodatki pojawiające się w Pseudo-Ezechielu świadczą o tym, że ten dokument jest jednym z najstarszych świadectw pozabiblijnej interpretacji wizji tronu-rydwanu Bożego z Księgi Ezechiela ${ }^{11}$.

Autor 4Q385 stwierdza, że Ezechiel zobaczył w wizji „blask rydwanu (נגה מרכבה)" (linia 6). W Księdze Ezechiela (Ez 1 i 10), na określenie niebiańskiego tronu Bożego nie pojawia się termin מרכבה, ,rydwan”, ale słowo כסא, „tron”, a ściślej wyrażenie דמות כסא, „coś, co jest podobne do tronu” (Ez 1,26; 10,1). Użycie w 4Q385 słowa wskazującego, że tron Boży posiada kształt i pełni

10 Zob. D. Dimant, J. Strugnell, The Merkabah Vision in Second Ezekiel (4Q384 4), „Revue de Qumran" 14 (1990), s. 343; C. Newsom, Songs of the Sabbath Sacrifice: A Critical Edition (HSS 27), Scholars Press, Atlanta 1985, s. 303 oraz s. 226.

11 Zob. D. Dimant, J. Strugnell, The Merkabah Vision in Second Ezekiel (4Q384 4), dz. cyt., s. 344-347; G.J. Brooke, Ezekiel in Some Qumran and New Testament Texts, w: The Madrid Qumran Congress. Proceedings of the International Congress on the Dead Sea Scrolls, Madrid 18-21 March, 1991 (STDJ 11), red. J. Trebolle Barrera, L. Vegas Montaner, Brill, Leiden 1992, t. I, s. 325; J.M. Scott, The Throne-Chariot Mysticism in Qumran and in Paul, w: Eschatology, Messianism, and the Dead Sea Scrolls (SDSSRL), red. C.A. Evans, P.W. Flint, Eerdmans Publishing Company, Grand Rapids - Cambridge 1997, s. 103; G.T. Manning, Echoes of a Prophet. The Use of Ezekiel in the Gospel of John and in Literature of the Second Temple Period (JSNTSup 270), T\&T Clark International, London - New York 2004, s. 71; M. Brady, Biblical Interpretation in the 'Pseudo-Ezekiel' Fragments (4Q383-391) from Cave Four, w: Biblical Interpretation at Qumran (SDSSRL), red. M. Henze, Eerdmans Publishing Company, Grand Rapids - Cambridge 2005, s. 97; M. Parchem, Księga Ezechiela w Qumran, dz. cyt., s. 124-127. 
funkcję rydwanu może sugerować, że dla autora tego dokumentu jest ono swoistego rodzaju terminem technicznym na określenie wizji Ezechiela ${ }^{12}$.

Termin נגה, „blask, jasność, światłość”, pojawia się kilkakrotnie w biblijnej wizji tronu Bożego (Ez 1,4.13.27.28; 10,4). Kilkakrotnie oznacza nie tyle źródło światłości, co raczej blask i jasność, które z tego źródła wypływają, stąd pojawia się w łączności z różnego rodzaju zjawiskami towarzyszącymi teofanii, między innymi emanuje z ognia (Ez 1,4.13.27) i jest porównywany do tęczy $(\mathrm{Ez} 1,28)$. W Ez 10,4 jest mowa o „blasku chwały JHWH” w kontekście obecności Boga w Świątyni: „I wypełnił Świątynię obłok, a dziedziniec został napełniony blaskiem chwały JHWH (את נגה כבוד יהוה)". Podobny motyw, mianowicie łączenie blasku (נגה) z Bogiem, pojawia się w Księdze Izajasza, gdzie blask ognia jest synonimem chwały Bożej osłaniającej Jerozolimę i jej mieszkańców (Iz 4,5) oraz w Księdze Habakuka, gdzie stwierdza się, że w blasku skrywa się moc Boga (Ha $3,4)^{13}$. Warto zauważyć, że w Pieśniach ofiary szabatowej pojawia się wyrażenie „dzieła blasku (ומעשי נוגה)" w opisie chwały Bożej (4Q405 frag. 20, kol. 2 + frag. 21-22, linie 10-11), natomiast w Blogosławieństwach i przekleństwach występuje zwrot „płomienie blasku (ושביבי נוגה)" w kontekście opisu błogosławieństw Boga w Jego niebiańskim sanktuarium (4Q286 frag. 1, kol. 2, linia 3). Jednakże połączenie słowa נגה, ,blask”, z terminem מרכבה, ,rydwan”, użytym w sensie technicznym na oznaczenie tronu-rydwanu Bożego, pojawia się jedynie w 4Q385 frag. $6^{14}$, co jest wyraźnym świadectwem interpretacji wzbogacającej motyw niebiańskiego tronu Boga z biblijnej wizji proroka Ezechiela. Użycie przez autora 4Q385 tego rodzaju terminologii jest pewnego rodzaju wytyczeniem sposobu interpretacji niebiańskiego tronu Boga, co swój pełny wyraz znalazło w późniejszych spekulacjach mistyki żydowskiej (np. Ma ‘ăśēh merkābāh, §596).

\subsection{Pieśni ofiary szabatowej (4Q405 frag. 20, kol. 2 + frag. 21-22)}

Dokument określony jako Pieśni ofiary szabatowej (lub Liturgia anielska) ma charakter liturgiczny i zawiera zbiór trzynastu pieśni przeznaczonych na kolejne szabaty roku. Treścią pieśni jest opis liturgii sprawowanej w niebiosach przez istoty niebiańskie. Na szczególną uwagę zasługuje niezwykle bogata terminologia

12 Zob. G.T. Manning, Echoes of a Prophet, dz. cyt., s. 71; D. Arbel, 'A Chariot of Light Borne by Four Bright Eagles': Eve's Vision of the Chariot in the Greek Life of Adam and Eve, w: With Letters of Light. Studies in the Dead Sea Scrolls, Early Jewish Apocalypticism, Magic, and Mysticism. Fs. R. Elior (Ekstasis, 2), red. D. Arbel, A. Orlov, De Gruyter, Berlin - New York 2011, s. 272.

13 Zob. H. Eising, H.-J. Fabry, nāgah, nōgah, negōhôt, w: Theological Dictionary of the Old Testament, red. G.J. Botterweck, H. Ringgren, H.-J. Fabry, tt. D.E. Green, Eerdmans, Grand Rapids - Cambridge 1998, t. IX, s. 186.

14 Zob. D. Dimant, 4QPseudo-Ezechiel a (DJD 30), dz. cyt., s. 45; zob. też D.J.A. Clines, i in., The Dictionary of Classical Hebrew, Sheffield Academic Press, Sheffield 2001, t. V, s. 605. 
angelologiczna. Liczne wezwania do wielbienia Boga mogą wskazywać, że członkowie wspólnoty qumrańskiej uważali kult sprawowany przez aniołów w Świątyni niebiańskiej za idealny, w którym sami również mogą uczestniczyć już na ziemi poprzez modlitwę i wierne praktykowanie Tory. Dokument zachował się w kilku rękopisach odkrytych w Qumran (4Q400-407; 11Q17) i na Masadzie (Mas1k), które pochodzą z okresu od pierwszej połowy I wieku przed Chr. do połowy I wieku po Chr.

Motyw znajdującego się w miejscu najświętszym Świątyni niebiańskiej tronu-rydwanu, na którym zasiada chwała (כבור) Boga, pojawia się w pieśni dwunastej (4Q405 frag. 20, kol. 2 + frag. 21-22), w kontekście opisu wielbienia Boga przez różne istoty niebiańskie, które są tutaj określane jako cherubiny, bogowie, posłańcy, duchy.

4Q405 frag. 20, kol. 2 + frag. 21-22, linie 6-14 ${ }^{15}$ :

6 Dla mas[kila. Pieśni ofiary] dwunastego szabatu [...]

7 [...cu]downa, i wywyższajcie Go stosownie do chwaty, w przybyt [ku...] wiedzy. Upadaja przed obliczem Jego [cheru]bini i błogostawia, gdy wstaja. Głos szeptu bogów

8 [jest styszalny,] i dźwięk uwielbienia; gdy wznosza swoje skrzydła, głos [szept]u bogów. Konstrukcję tronu rydwanu błogostawia ponad firmamentem cherubinów,

9 [i maje]stat firmamentu światta uwielbiaja spod siedziby chwaly Jego. A gdy kola poruszaja się, postańcy świętości powracaja. Wychodza spomiędzy

10 [o]si chwalebnych Jego, jak gdyby postacie ognia, duchy świętości najświętszej (sa) dookoła w postaci potoków ognia na podobieństwo bursztynu. I dzieła

11 blasku o chwalebnej barwie, cudownych kolorach, nieskazitelnie połaczonych, duchy, bogowie żywi, poruszaja się nieustannie z chwała rydwanów

12 cudownych. I głos szeptu blogosławieństwa jest w dźwięku ich ruchu. I wychwalaja świętość, gdy wracaja swoimi drogami. Gdy podnosza się, wywyższaja cudownie, a gdy zatrzymuja się,

13 [staw]ają. I glos pieśni radosnych cichnie, a szept blogostawieństwa bogów jest we wszystkich obozach bogów, [i] głos pochw [at]

${ }_{14}[. .$.$] spośród wszystkich choragwi i[ch] na stron[ach ich... i] raduja się wszystkie$ oddziały ich, każdy z nich na stanowisku [swoim.]

15 Tekst został opublikowany w: C. Newsom, i in., Angelic Liturgy: Songs of the Sabbath Sacrifice (4Q400-407, 11Q17, Mas1k), w: The Dead Sea Scrolls. Hebrew, Aramaic, and Greek Texts with English Translations (PTSDSSP), Angelic Liturgy: Songs of the Sabbath Sacrifice, red. J.H. Charlesworth, i in., Mohr Siebeck, Tübingen - Westminster John Knox Press, Louisville 1999 , t. 4B, s. 92-95. 
Treść pieśni nawiązuje do wizji z Księgi Ezechiela (Ez 1; 10; 43), interpretowanej w świetle innych tekstów biblijnych (m.in. 1 Krl 19,11-12; Ps 68 17-20; Dn 7,9-10) ${ }^{16}$.

Początek pieśni (linie 6-7) zachowały się w stanie bardzo fragmentarycznym. Po podaniu daty (tj. „dwunasty szabat”), następuje wezwanie do wielbienia Boga, a ściślej Jego chwały, w Świątyni niebiańskiej. W linii 7 w odniesieniu do Boga, tj. Jego obecności w Świątyni, został użyty termin „chwała” w status absolutus z rodzajnikiem określonym (הכבור), co jest dość niezwykłe (ale por. wyrażenie , siedziba chwały jego” w linii 9), gdyż zwykle jest używane wyrażenie z dodanym imieniem własnym Boga, a więc , ,chwała JHWH” (lub w połączeniu z zaimkiem odnoszącym się do Boga), która wypełnia Przybytek ( $\mathrm{Wj} 40,35$; Ps 26,8), czy też Świątynię (Ez 43,4-5; 44,4; 1 Krl 8,10-11; 2 Krn 5,13-14; 7,1). Takie użycie terminu ,chwała” przez autora 4Q405 przywołuje na myśl wyrażenie „chwała wielka”, jako tytułu Boga w innych pismach z okresu Drugiej Świątyni (1 Hen 14,20; 102,3; Testament Lewiego 3,4; Wniebowzięcie Izajasza 9,37) ${ }^{17}$. Na miejsce, gdzie aniołowie sprawują liturgię, wskazuje występujący w linii 7 termin משכן, ,przybytek”, który pojawia się jeszcze w 4Q403 frag. 1, kol. 2, linii 10 (,przybytek główny wysokości chwały królestwa jego”). Chociaż dalsza część tekstu jest uszkodzona, to jednak proponowana jego rekonstrukcja jako „przybyte[k Boga] wiedzy” nawiązuje do biblijnego wyrażenia ,przybytek JHWH” (np. Kpł 17,4; Lb 16,9; 17,28; 1 Krn 16,29). Mając na uwadze liczne aluzje do Księgi Ezechiela, obecne w tej pieśni, L.H. Schiffman zwraca uwagę, że termin משככן, „przybytek” jest synonimem słowa מקדש,,,sanktuarium” w Ez 37,26-27: „I zawrę z nimi przymierze pokoju. Będzie to przymierze wieczne z nimi. I osadzę ich, i pomnożę ich, i umieszczę sanktuarium moje (מקדשי) pośród nich na wieki. I będzie przybytek mój (משכני) nad nimi, i będę dla nich Bogiem, a oni będą dla mnie ludem"18.

16 Zob. C. Newsom, Songs of the Sabbath Sacrifice: A Critical Edition, dz. cyt., s. 55-56; tejże, Merkabah Exegesis in the Qumran Sabbath Shirot, „Journal of Jewish Studies” 38 (1987), s. 19-29; tejże, Throne, w: Encyclopedia of the Dead Sea Scrolls, red. L.H. Schiffman, J.C. VanderKam, i in., Oxford University Press, Oxford 2000, t. II, s. 946; G.T. Manning, Echoes of a Prophet, dz. cyt., s. 43-47.

17 Zob. C. Newsom, Songs of the Sabbath Sacrifice, dz. cyt., s. 312; J.R. Davila, Liturgical Works (Eerdmans Commentaries on the Dead Sea Scrolls, 6), Eerdmans, Grand Rapids 2000, s. 150; C.H.T. Fletcher-Louis, All the Glory of Adam: Liturgical Anthropology in the Dead Sea Scrolls (STDJ 42), Brill, Leiden 2002, s. 346; zob. też L.H. Schiffman, Merkavah Speculation at Qumran: The 4Q Serekh Shirot 'Olat ha-Shabbat, w: Mystics, Philosophers, and Politicians: Essays in Jewish Intellectual History, Fs. A. Altmann, red. J. Reinharz, i in., Duke University Press, Durham 1982, s. 35-36.

18 Zob. L.H. Schiffman, Merkavah Speculation at Qumran, dz. cyt., s. 36; zob. też C. Newsom, Songs of the Sabbath Sacrifice, dz. cyt., s. 312. 
Kolejnym elementem opisu uwielbienia chwały Bożej jest dźwięk będący efektem poruszania się cherubinów, o którym autor pieśni szabatowej stwierdza w linii 7, że był to „głos szmeru bogów (קול דממת אלוהים)". Te słowa wyraźnie nawiązują do wyrażenia „głos szmeru cichego" z $1 \mathrm{Krl}$ 19,12, które pojawia się w kontekście objawienia się Boga Eliaszowi: „I oto, JHWH przechodził: i wiatr wielki i silny, kruszący góry i łamiący skały przed JHWH, nie był JHWH w wietrze; a po wietrze wstrząs, nie był JHWH we wstrząsie; a po wstrząsie ogień, nie był JHWH w ogniu; a po ogniu głos szmeru cichego (קול דממת דקה)" (1 Krl 19,11-12). Warto zwrócić uwagę, że w $1 \mathrm{Krl}$ 19,12 to wyrażenie jest identyfikowane z obecnością Bożą, a więc staje się synonimem samego Boga. W późniejszej tradycji żydowskiej dźwięk poruszających się cherubinów był rozumiany jako głos uwielbienia i adoracji (np. targum do Ez 1,24-25; zob. 4Q405 frag. 20, kol. $2+$ frag. 21-22, linia 12), zaś w literaturze mistycznej jest przedmiotem dalszych rozważań (np. Ma ăšséh merkābāh, §552; §596) ${ }^{19}$.

W linii 8 autor 4Q405, wskazując na przedmiot uwielbienia płynący ze strony istot niebiańskich, używa wyrażenia תבנית כסא מרכבה, ,konstrukcja ${ }^{20}$ tronu rydwanu". Mając na uwadze fakt, że linie 8-9 nawiązują do Ez 1,26, D. Dimant wskazuje, iż zwrot תבנית כסא, ,konstrukcja tronu” może być synonimem wyrażenia דמות כסט, ,coś, co jest podobne do tronu”, ale równie dobrze może być aluzją do zwrotu תבנית המרכבה, ,konstrukcja rydwanu” z 1 Krn 28,18, który występuje w połączeniu z wzmianką o złotych cherubach okrywających swoimi skrzydłami Arkę Przymierza znajdującą się w miejscu najświętszym Świątyni ${ }^{21}$. Ponieważ Ezechiel nie używa terminu מרכבה, ,rydwan”, stąd można przypuszczać, że wyrażenie „konstrukcja tronu rydwanu”, znajdujące się w Pieśni ofiary szabatowej z Qumran, jest interpretacją Ez 1,26 w świetle tekstu z 1 Krn 28,18. Innymi słowy, termin בסט, ,tron” został użyty przez autora 4Q405 w celu wyjaśnienia określenia מרכבה, ,rydwan”, wyrażając prawdę o tym, że chwała Boża, obecna w miejscu najświętszym Świątyni niebiańskiej, unosi się na tronie, który posiada kształt rydwanu (zob. też 3 Hen 46,2: כסא המרכבה, ,tron rydwanu”)" Takiej identyfikacji mogły też sprzyjać wzmianki o kołach, które są obecne w opisach niebiańskiego tronu Boga (np. Ez 1,15-21; 10,2; Dn 7,9; 1 Hen 14,18). Można

19 Zob. C. Newsom, Songs of the Sabbath Sacrifice, dz. cyt., s. 313-314; zob. też L.H. Schiffman (Merkavah Speculation at Qumran, dz. cyt., s. 36-37), który podaje dalsze liczne przykłady.

20 Słowo תבנית oznacza zarówno „konstrukcję, kształt, model, wzorzec”, jak też „obraz, podobizna, podobieństwo", zob. D.J.A. Clines, i in., The Dictionary of Classical Hebrew, Sheffield Academic Press, Sheffield 2011, t. VIII, s. 590; z powodu wieloznaczności tego terminu, trudno jednoznacznie stwierdzić, w jakim sensie został on użyty w tym tekście, zob. C. Newsom, Songs of the Sabbath Sacrifice, dz. cyt., s. 314; P.A.F. Church, Hebrews and the Temple: Attitudes to the Temple in the Second Temple Judaism and in Hebrews (NovTSup 171), Brill, Leiden 2017, s. 137-138.

21 Zob. C. Newsom, Songs of the Sabbath Sacrifice, dz. cyt., s. 314.

22 Zob. L.H. Schiffman, Merkavah Speculation at Qumran, dz. cyt., s. 38; J.R. Davila, Liturgical Works, dz. cyt., s. 151. 
zatem stwierdzić, że wyrażenie „konstrukcja tronu rydwanu” z 4Q405 jest swoistego rodzaju kombinacją tekstów z Ez 1,26 oraz 1 Krn 28,18 (zob. też Syr 49,8, gdzie termin „rydwan” pojawia się w znaczeniu technicznym na określenie tronu Bożego), które stanowią świadectwo interpretacji tronu-rydwanu z wizji Ezechiela.

W dalszym opisie uwielbienia chwały Boga przez istoty niebiańskie, synonimem wyrażenia ,konstrukcja tronu rydwanu” (linia 8) są słowa מושב כבודו, „siedziba chwały Jego” (linia 9). Jak zauważa L.H. Schiffman, wyrażenie ,siedziba chwały Jego", podobnie jak zwroty synonimiczne (zob. np. מושב יקרכה,,,siedziba honoru Twego" w 4Q286 frag. 1, kol. 2, linia 1), występują często w późniejszej literaturze na temat pałaców niebiańskich (m.in. Ma 'áśéh merkābāh, §550; §557; $\S 559 ; \S 564)^{23}$.

Warto zwrócić uwagę na wyrażenie מעשי נוגה, ,dzieła blasku” (linie 10-11), które przywołuje na myśl częste użycie terminu נגונר, „blask”, w wizji Ezechiela

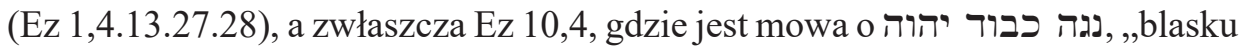
chwały JHWH". W 4Q385 o niebiańskim tronie mówi się jako o נגה מרכבה, „blasku rydwanu” (frag. 6, linia 6). Motyw blasku jest częstym elementem opisów niebiańskiego tronu-rydwanu Bożego w literaturze mistycznej (np. Ma ăšséh merkābāh, §596) ${ }^{24}$.

W opisie chwały Bożej wielbionej przez istoty niebiańskie dwukrotnie pojawia się motyw ognia (linia 10). Najpierw stwierdza się, że istoty niebiańskie - określone jako „duchy” - mają wygląd ,jak gdyby postaci ognia (כמראי אש)" (por. Ez $1,13.27 ; 8,2)$, a następnie pojawia się wzmianka o tym, że otaczają one tron Boży

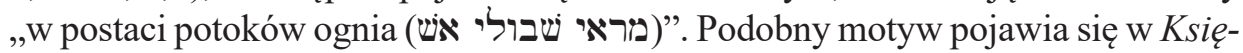
dze strażników, gdzie jest mowa o tym, że „spod wysokiego tronu wypływały potoki ognia płonącego" (1 Hen 14,19), co w odnalezionym aramejskim fragmencie brzmi po rekonstrukcji tekstu, jako ,potoki [ognia]” (4Q204 frag. 1, kol. 7, linie 1-2). W tradycji biblijnej o rzekach ognia jest mowa w Dn 7,10: „Rzeka ognia

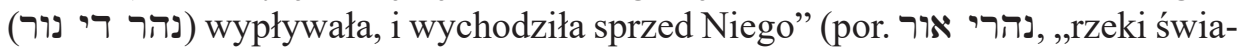
tła” w 4Q405, frag. 15, linia 2). W późniejszej literaturze o charakterze apokaliptycznym i mistycznym motyw potoków/rzek ognia stał się stałym elementem opisu tronu Bożego ${ }^{25}$.

${ }^{23}$ Zob. L.H. Schiffman, Merkavah Speculation at Qumrans, dz. cyt., s. 38-39; C. Newsom, Songs of the Sabbath Sacrifice, dz. cyt., s. 314-315; zob. też B. Nitzan, 4QBerakhot (4Q286-290): A Preliminary Report, w: New Qumran Texts and Studies: Proceedings of the First Meeting of the International Organization for Qumran Studies, Paris 1992 (STDJ 15), red. G.J. Brooke, Brill, Leiden 1994, s. 58.

24 Zob. L.H. Schiffman, Merkavah Speculation at Qumrans, dz. cyt., s. 41; C. Newsom, Songs of the Sabbath Sacrifice, dz. cyt., s. 316; J.R. Davila, Liturgical Works, dz. cyt., s. 152.

25 Zob. H. Bietenhard, Die himmlische Welt im Urchristentum und Spätjudentum (WUNT 2), Mohr Siebeck, Tübingen 1951, s. 75; L.H. Schiffman, Merkavah Speculation at Qumran, dz. cyt., s. 40; C. Newsom, Songs of the Sabbath Sacrifice, dz. cyt., s. 315-316; J.R. Davila, Liturgical Works, dz. cyt., s. 140. 
Autor dwunastej pieśni szabatowej wiele uwagi - podobnie jak ma to miejsce w wizji Ezechiela - poświęca szczegółowemu opisowi istot niebiańskich, wysławiających Boga zasiadającego na tronie-rydwanie w niebiańskiej Świątyni. W sposób szczególny zostaje podkreślony fakt niezliczonej liczby aniołów, które otaczają tron-rydwan Boży (linia 10). W tradycji biblijnej o wielkiej liczbie istot niebiańskich otaczających tron Boga jest mowa w Dn 7,10: „tysiąc tysięcy służyło $\mathrm{Mu}$, i miriady miriad stały przed Nim". Podobny motyw pojawia w Księdze strażników: „dziesięć tysięcy razy dziesięć tysięcy stało przed Nim” (1 Hen 14,22) oraz w Księdze gigantów: „sto s]etek służy mu, tysiąc tysięcy [oddaje] mu [cześć]” (4Q530, kol. 2, linia 17). Warto zauważyć, że we wszystkich przypadkach - podobnie jak w dwunastej pieśni szabatowej (linie 7-9, 12) - aniołowie, którzy otaczają niebiański tron, wysławiają i wielbią zasiadającego na nim Boga. Motyw niezliczonej liczby aniołów otaczających niebiański tron i wielbiących Boga jest częstym elementem opisów w późniejszej literaturze mistycznej. Warto zwrócić uwagę, że w 4Q405 aniołowie wielbiący Boga w Świątyni niebiańskiej są ukazani jako armia, o czym świadczy terminologia militarna użyta w opisie ich organizacji, mianowicie מחני אלוהים, ,obozy bogów”, oraz [דגליה], ,chorągwie i[ch]” (linie 13-14). Podobna terminologia jest używana w odniesieniu do organizacji Izraela podczas wędrówki przez pustynię w drodze do Kanaanu (Lb 1-2; 10) oraz wojska, w skład którego wchodzą aniołowie i ludzie podczas wojny eschatologicznej w Zwoju wojny (zob. „obozy świętych Jego” w 1QM 3,5; ,obozy Boga” w 1QM 4,9; , ,chorągwie Boga" w 1QM 3,6). Używanie terminologii militarnej w odniesieniu do organizacji aniołów pojawia się w 3 Hen 19,6 i jest częste w późniejszej literaturze rabinicznej ${ }^{26}$.

Warto zauważyć, że w Pieśniach ofiary szabatowej termin מרכבה kilkakrotnie pojawia się w liczbie mnogiej, jako מרכבות, ,rydwany”, co bez wątpienia jest określeniem istot niebiańskich. W 4Q403 frag. 1, kol. 2, linia 15 ,rydwany” pojawiają się w paralelizmie z „cherubinami”: „chwalcie wspólnie rydwany debiru Jego (מרכבות דבירו), i błogosławcie cudownie cherubini ich i koła ich”. W 4Q405 frag. 20, kol. 2 + frag. 21-22, linia 3 (pieśń jedenasta) pojawia się wyrażenie , מרכבות כבודו, ,rydwany chwały Jego”. W 4Q405 frag. 20, kol. 2 + frag. 21-22, linia 11 termin „rydwany” pojawia się ze słowem „chwała”, które odnosi się do Boga: „poruszają się nieustannie z chwałą rydwanów (עם כבוד מרכבות) cudownych". Motyw wielu tronów-rydwanów (מרכבות), które uczestniczą w niebiańskiej liturgii pojawia się w późniejszej literaturze mistycznej: „,w pierwszym pałacu stoi cztery tysiące miriad rydwanów ognia (...); w drugim pałacu stoi sto tysięcy miriad rydwanów ognia (...); w trzecim pałacu stoi dwieście tysięcy miriad rydwanów ognia (...); w czwartym pałacu stoi tysiąc tysięcy-miriad rydwanów ognia (...);

26 Przykłady podają m.in. L.H. Schiffman, Merkavah Speculation at Qumran, dz. cyt., s. 44-45; J.R. Davila, Liturgical Works, dz. cyt., s. 152-153. 
w piątym pałacu stoi cztery tysiące tysięcy-miriad rydwanów ognia (...); w szóstym pałacu stoi czterdzieści tysięcy tysięcy-miriad rydwanów ognia (...); w siódmym pałacu stoi sto tysięcy tysięcy-miriad rydwanów ognia (...)", po opisie liczby rydwanów ognia następuje opis sprawowanej przez istoty niebiańskie liturgii: „w pierwszym pałacu rydwany ognia mówią: święty, święty, święty (...); w drugim pałacu rydwany ognia mówią: błogosławiona jest chwała JHWH (...); w trzecim pałacu rydwany ognia mówią: błogosławione jest imię chwały Jego królestwa (...)" (Ma ăšśêh merkābāh, §554-555; zob. też Wniebowzięcie Izajasza 7; Hekalot zutarti, §413-419). Motyw wielu tronów pojawia się w Dn 7,9: „Patrzyłem, aż zostały postawione trony (כרסון) i Starowieczny zasiadł", co najprawdopodobniej odnosi się do Boga oraz do istot niebiańskich tworzących Jego dwór. Wydaje się, że motyw tronów-rydwanów występujący w Pieśniach ofiary szabatowej i późniejszych pismach na temat pałaców niebiańskich nawiązuje do Iz 66,15: „Bo oto JHWH nadejdzie jak ogień, i jak nawałnica rydwany Jego (מרכבתיו)", jak również do Ps 68,18: „Rydwanów Boga są dwie miriady (dwadzieścia tysięcy), tysiąc razy powtórzone, Pan jest wśród nich (אדני בם)", co w Pesikta de Rab Kahana jest wyjaśnione jako „tysiące rydwanów posługujących aniołów zstąpiło ze Świętym, niech będzie błogosławiony, na Synaj” (PRK 12,22)27.

\section{PODSUMOWANIE}

Z jednej strony istnienie w pełni rozwiniętego nurtu żydowskiej mistyki, w której centralnym motywem była Świątynia w niebiosach, ze znajdującym się w jej wnętrzu tronem Bożym o kształcie rydwanu (merkābāh), można datować na II wiek po Chr., na co wskazuje literatura na temat pałaców niebiańskich (hêkālôt). Z drugiej zaś strony uzasadniona wydaje się opinia, że początków mistyki merkābāh należy upatrywać znacznie wcześniej, a mianowicie na przełomie IV i III wieku przed Chr., co wiąże się z czasem powstania Ksiąg Kronik, gdzie po raz pierwszy termin merkābāh pojawia się w sensie technicznym, stosowanym w późniejszej mistyce żydowskiej jako określenie tronu-rydwanu Boga (1 Krn 28,18; zob. też podobne użycie w Księdze Syracha z początku II w. przed. Chr.: Syr 49,8). Z uwagi na to spostrzeżenie rodzi się pytanie o istnienie tradycji mistycznych w okresie pomiędzy ich początkami w IV-III wieku przed Chr. a ich pełnym rozwojem u zmierzchu starożytności i później, w średniowieczu. Wydaje się, że na wczesnym etapie mistyka merkābāh rozwijała się w ramach apokaliptyki, o czym świadczy obecność motywu tronu Bożego w niebiosach w Księdze strażników (1 Hen 14, 18-23), Księdze Daniela (Dn 7,9-10), jak również w Apokalipsie Abrahama (ApAbr 18). Odkrycie zwojów na Pustyni Judzkiej nad Morzem Martwym potwier-

27 Zob. C. Newsom, Songs of the Sabbath Sacrifice, dz. cyt., s. 237-238. 
dziło istnienie spekulacji na temat Świątyni w niebiosach, tronu Bożego o kształcie rydwanu oraz liturgii niebiańskiej. Chociaż trudno w jednoznaczny sposób wskazać bezpośredni związek między opisami tronu Bożego (merkābāh) w pismach qumrańskich a późniejszymi tekstami na temat pałaców niebiańskich, to jednak bez wątpienia w obydwu przypadkach chodzi o ten sam nurt tradycji religijnej. Należy podkreślić, że istotne elementy żydowskiej mistyki merkābāh, koncentrujące się wokół interpretacji tronu Bożego z wizji Ezechiela (Ez 1), są obecne zarówno w pismach qumrańskich (4Q385 frag. 6; 4Q405 frag. 20, kol. $2+$ frag. 21-22), jak i w późniejszej literaturze na temat pałaców niebiańskich (zwłaszcza Ma'aseh merkabah). Reasumując, można stwierdzić, że motyw tronu-rydwanu Bożego w pismach qumrańskich wskazuje na ciągłość rozwoju nurtu mistycznego, którego pierwsze ślady znajdują się w tekstach biblijnych, a który w całej pełni rozwinął się w późniejszej literaturze mistycznej.

\section{Bibliografia}

Abegg M.G., i in. (red.), The Dead Sea Scrolls Concordance, t. I: The Non-Biblical Texts from Qumran [Part One], Brill, Leiden - Boston 2003.

Arbel D., 'A Chariot of Light Borne by Four Bright Eagles': Eve's Vision of the Chariot in the Greek Life of Adam and Eve, w: With Letters of Light. Studies in the Dead Sea Scrolls, Early Jewish Apocalypticism, Magic, and Mysticism. Fs. R. Elior (Ekstasis, 2), red. D. Arbel, A. Orlov, De Gruyter, Berlin - New York 2011, s. 267-284.

Beentjes P.C., The Book of Ben Sira in Hebrew: A Text Edition of All Extant Hebrew Manuscripts and a Synopsis of All Parallel Hebrew Ben Sira Texts (Supplements to Vetus Testamentum, 68), Brill, Leiden 1997.

Bietenhard H., Die himmlische Welt im Urchristentum und Spätjudentum (Wissenschaftliche Untersuchungen zum Neuen Testament, 2), Mohr Siebeck, Tübingen 1951.

Brady M., Biblical Interpretation in the 'Pseudo-Ezekiel' Fragments (4Q383-391) from Cave Four, w: Biblical Interpretation at Qumran (Studies in the Dead Sea Scrolls and Related Literature), red. M. Henze, Eerdmans Publishing Company, Grand Rapids - Cambridge 2005, s. 88-109.

Brooke G.J., Ezekiel in Some Qumran and New Testament Texts, w: The Madrid Qumran Congress. Proceedings of the International Congress on the Dead Sea Scrolls, Madrid 18-21 March, 1991 (Studies on the Texts of the Desert of Judah, 11), red. J. Trebolle Barrera, L. Vegas Montaner, Brill, Leiden 1992, t. I, s. 317-337.

Church P.A.F., Hebrews and the Temple: Attitudes to the Temple in the Second Temple Judaism and in Hebrews (Supplements to Novum Testamentum, 171), Brill, Leiden 2017. 
Clines D.J.A., i in., The Dictionary of Classical Hebrew, Sheffield Academic Press, Sheffield 1993-2011, t. I-VIII.

Dan J., The Ancient Jewish Mysticism, MOD Books, Tel Aviv 1993.

Davila J.R., Hekhalot Literature in Translation: Major Texts of Merkavah Mysticism (Supplements to The Journal of Jewish Thought and Philosophy, 20), Brill, Leiden - Boston 2013.

Davila J.R., Liturgical Works (Eerdmans Commentaries on the Dead Sea Scrolls, 6), Eerdmans, Grand Rapids 2000.

Davila J.R., The Ancient Jewish Apocalypses and the Hekhalot Literature, w: Paradise Now: Essays on Early Jewish and Christian Mysticism (Society of Biblical Literature. Symposium Series, 11), red. A.D. DeConick, Society of Biblical literature, Atlanta 2006, s. 105-125.

Dimant D., 4QPseudo-Ezechiela, w: Qumran Cave 4. XXI: Parabiblical Texts, Part 4: Pseudo-Prophetical Texts (Discoveries in the Judaean Desert, 30), red. D. Dimant, Clarendon Press, Oxford 2001, s. $42-51$ (+ pl. I).

Dimant D., Resurrection, Restoration, and Time-Curtailing at Qumran, and in Early Judaism and Christianity, w: History, Ideology and Bible Interpretation in the Dead Sea Scrolls: Collected Studies (Forschungen zum Alten Testament, 90), red. D. Dimant, Mohr Siebeck, Tübingen 2014, s. 249-268.

Dimant D., The Apocalyptic Interpretation of Ezechiel at Qumran, w: Messiah and Christos. Studies in the Jewish Origins of Christianity (Texte und Studien zum antiken Judentum, 32), red. I. Gruenwald, i in., Mohr Siebeck, Tübingen 1992, s. 31-51.

Dimant D., J. Strugnell, The Merkabah Vision in Second Ezekiel (4Q384 4), „Revue de Qumran” 14 (1990), s. 331-348.

Eising H., H.-J. Fabry, nāgah, nōgah, negōhôt, w: Theological Dictionary of the Old Testament, red. G.J. Botterweck, H. Ringgren, H.-J. Fabry, tł. D.E. Green, Eerdmans, Grand Rapids - Cambridge 1998, t. IX, s. 186-187.

Elior R., The Merkavah Tradition and the Emergence of Jewish Mysticism, w: Sino-Judaica: Jews and Chinese in Historical Dialogue. An International Colloquium, Nanjing, 11-19 October, 1996, red. A. Oppenheimer, Tel Aviv University, Tel Aviv 1999, s. 101-158.

Fletcher-Louis C.H.T., All the Glory of Adam: Liturgical Anthropology in the Dead Sea Scrolls (Studies on the Texts of the Desert of Judah, 42), Brill, Leiden 2002.

Garcia Martinez F., L'interpretation de la Torah d'Ezechiel dans les ms. de Qumran, „Revue de Qumran” 13 (1988), s. 441-452.

Garcia Martinez F., The Apocalyptic Interpretation of Ezekiel in the Dead Sea Scrolls, w: Interpreting Translation: Studies on the LXX and Ezekiel. Fs. J. Lust (Bibliotheca Ephemeridum Theologicarum Lovaniensium, 192), red. F. Garcia Martinez, M. Vervenne, Peeters Publishers, Leuven 2005, s. 163-176. 
Gothenet E., Influence d'Ezechiel sur la spiritualite de Qumran, „Revue de Qumran" 13 (1988), s. 431-439.

Gruenwald I., Apocalyptic and Merkavah Mysticism (Ancient Judaism and Early Christianity, 90), Brill, Leiden - Boston 2014 ( $2^{\text {nd }}$ revised edition).

Gruenwald I., From Apocalypticism to Gnosticism: Studies in Apocalypticism, Merkavah Mysticism and Gnosticism, Peter Lang, Frankfurt 1988.

Halperin D.J., The Faces of the Chariot: Early Jewish Responses to Ezekiel's Vision (Texte und Studien zum antiken Judentum, 16), Mohr Siebeck, Tübingen 1988.

Himmelfarb M., Heavenly Ascent and the Relationship of the Apocalypses and the Hekhalot Literature, „Hebrew Union College Annual” 59 (1988), s. 73-100.

Manning G.T., Echoes of a Prophet. The Use of Ezekiel in the Gospel of John and in Literature of the Second Temple Period (Journal for the Study of the New Testament. Supplement Series, 270), T\&T Clark International, London - New York 2004.

Muchowski P., Rękopisy znad Morza Martwego, Qumran, Wadi Murabba 'at, Masada, Nachal Chewer (Biblioteka Zwojów. Tło Nowego Testamentu, 5), Kraków 2000.

Newsom C., i in., Angelic Liturgy: Songs of the Sabbath Sacrifice (4Q400-407, 11Q17, Mas 1k), w: The Dead Sea Scrolls. Hebrew, Aramaic, and Greek Texts with English Translations (The Princeton Theological Seminary Dead Sea Scrolls Project), Angelic Liturgy: Songs of the Sabbath Sacrifice, red. J.H. Charlesworth, i in., Mohr Siebeck, Tübingen - Westminster John Knox Press, Louisville 1999, t. 4B.

Newsom C., Merkabah Exegesis in the Qumran Sabbath Shirot, „Journal of Jewish Studies" 38 (1987), s. 11-30.

Newsom C., Mysticism, w: Encyclopedia of the Dead Sea Scrolls, red. L.H. Schiffman, J.C. VanderKam, i in., Oxford University Press, Oxford 2000, t. I, s. 591-594.

Newsom C., Songs of the Sabbath Sacrifice: A Critical Edition (Harvard Semitic Studies, 27), Scholars Press, Atlanta 1985.

Newsom C., Throne, w: Encyclopedia of the Dead Sea Scrolls, red. L.H. Schiffman, J.C. VanderKam, i in., Oxford University Press, Oxford 2000, t. II, s. 946-947.

Nitzan B., 4QBerakhot (4Q286-290): A Preliminary Report, w: New Qumran Texts and Studies: Proceedings of the First Meeting of the International Organization for Qumran Studies, Paris 1992 (Studies on the Texts of the Desert of Judah, 15), red. G.J. Brooke, Brill, Leiden 1994, s. 53-71.

Odeberg H., 3 Enoch or the Hebrew Book of Enoch, Cambridge University Press, London 1928 (reprint: Ktav, New York 1973).

Parchem M., Księga Ezechiela w Qumran, „Collectanea Theologica” 77 (2007), nr 4, s. 103-138. 
Rowland C., Morray-Jones C.R.A., The Mystery of God: Early Jewish Mysticism and the New Testament (Compendia Rerum Iudaicarum ad Novum Testamentum, 12), Brill, Leiden - Boston 2009.

Schäfer P., Geniza Fragmente zur Hekhalot Literatur (Texte und Studien zum antiken Judentum, 6), Mohr Siebeck, Tübingen 1984.

Schäfer P., Synopse zur Hekhalot Literatur (Texte und Studien zum antiken Judentum, 2), Mohr Siebeck, Tübingen 1981.

Schäfer P., The Origins of Jewish Mysticism (Texte und Studien zum antiken Judentum, 112), Mohr Siebeck, Tübingen 2009.

Schiffman L.H., Merkavah Speculation at Qumran: The 4Q Serekh Shirot 'Olat ha-Shabbat, w: Mystics, Philosophers, and Politicians: Essays in Jewish Intellectual History, Fs. A. Altmann, red. J. Reinharz, i in., Duke University Press, Durham 1982, s. 15-47.

Scholem G., Jewish Gnosticism, Merkabah Mysticism, and Talmudic Tradition, The Jewish Theological Seminary of America, New York 1965.

Scholem G., Mistycyzm żydowski i jego główne kierunki, tł. I. Kania, Spółdzielnia Wydawnicza „Czytelnik”, Warszawa 1997.

Scott J.M., The Throne-Chariot Mysticism in Qumran and in Paul, w: Eschatology, Messianism, and the Dead Sea Scrolls (Studies in the Dead Sea Scrolls and Related Literature), red. C.A. Evans, P.W. Flint, Eerdmans Publishing Company, Grand Rapids - Cambridge 1997, s. 101-119.

Skehan P.W., Di Lella A.A., The Wisdom of Ben Sira: A New Translation with Notes, Introduction and Commentary (Anchor Bible, 39), Doubleday, New York 1987.

Tronina A., Pierwsza Księga Kronik. Wstęp, przekład z oryginału, komentarz (Nowy Komentarz Biblijny. Stary Testament, X/1), Edycja Świętego Pawła, Częstochowa 2015.

Wacholder B.Z., Ezekiel and Ezekielianism as Progenitors of Essenianism, w: The Dead Sea Scrolls. Forty Years of Research (Studies on the Texts of the Desert of Judah, 10), red. D. Dimant, U. Rappaport, Brill, Leiden - Magnes Press, Jerusalem 1992, s. 186-196.

\section{Streszczenie}

Obraz tronu Bożego o kształcie rydwanu (merkābāh) z wizji Ezechiela (Ez 1,4-28; 10; zob. też $1 \mathrm{Krl} 22,19$; Iz 6,1-4) stanowił główny przedmiot rozważań w mistyce żydowskiej, której pierwsze elementy pojawiają się w pismach apokaliptycznych (zob. Dn 7,9-10; 1 Hen 14,18-23; ApAbr 18; Ap 4). Nurt mistycznej interpretacji tronu-rydwanu Bożego określany, jako ma ‘̆śśêh merkābāh, „, dzieło tronu-rydwanu" (zob. Miszna, Chagigah, 2,1), rozwinął się w pierwszych wiekach po narodzeniu Chrystusa i w okresie średniowiecza (zob. 3 Hen, pisma na temat 
pałaców niebiańskich). Odkrycie zwojów na Pustyni Judzkiej nad Morzem Martwym wskazuje, że mistyczne spekulacje na temat tronu-rydwanu Bożego były podejmowane w pewnych kręgach żydowskich już w czasach przedchrześcijańskich i są swoistego rodzaju pomostem między pierwszymi wzmiankami o nich (zob. $1 \mathrm{Krn}$ 28,18; Syr 49,8) a początkiem pełnego ich rozwoju (II-III w. po Chr.). W niniejszym artykule została przeprowadzona analiza tekstów qumrańskich będących świadectwem mistyki, w których pojawia się termin merkābāh, mianowicie Pseudo-Ezechiel (4Q385 frag. 6) oraz Pieśni ofiary szabatowej (4Q405 frag. 20, kol. $2+$ frag. 21-22).

Słowa kluczowe: tron-rydwan Boży, Qumran, merkābāh, mistycyzm, literatura na temat pałaców niebiańskich (hêkālôt)

The Theme of the Chariot-Throne in Heavens in the Qumran Writings and the Beginnings of the Merkābāh Mysticism

\section{Summary}

The theme of the divine throne shaped as a chariot (merkābāh), as it appears in the Ezekiel's vision (Ezek 1:4-28; 10; see also $1 \mathrm{Kgs}$ 22:19; Isa 6:1-4), was the main topic within the Jewish mysticism and its first elements appear in the apocalyptic writings (see Dan 7:9-10; 1 En. 14:18-23; Apoc. Abr. 18; Rev 4). The mystical interpretation current of the divine throne-chariot referred to as ma 'ăśêh merkābāh - "the work of throne-chariot" (Mishnah, Hag. 2:1) developed in the time directly posterior to Jesus' birth and in the Middle Ages (see 3 Enoch, writings on the heavenly palaces). The discovery of the Dead Sea scrolls in the Judean Desert proves that mystical speculations were undertaken in some Jewish circles as early as in the pre-Christian times and that they form a kind of a bridge between their first occurrences (see $1 \mathrm{Chr} 28: 18$; Sir 49:8) and the beginning of their full expansion (1-2 cent. AD). This essay explores and discusses the Qumran texts that testify to the merkābā mysticism, namely, Pseudo-Ezekiel (4Q385 frg. 6) and The Songs of the Sabbath Sacrifice (4Q405 frg. 20, col. 2 + frgs. 21-22).

Keywords: throne-chariot of God, Qumran, merkābāh, mysticism, hêkālôt literature 